\title{
NON-CONVENTIONAL P SOURCES FOR ZEBU COWS IN BRAZIL ${ }^{1}$
}

\author{
D.M.S.S. VITTI ${ }^{2}$; A.L. ABDALLA ${ }^{2}$; H.O.S. LOPES $^{3}$; E.A. PEREIRA ${ }^{3}$; C.F. MEIRELLES ${ }^{4}$ \\ ${ }^{2}$ Centro de Energia Nuclear na Agricultura/USP, C.P. 97, CEP: 13416-000, Piracicaba-SP. \\ ${ }^{3}$ Centro de Pesquisas Agropecuárias do Cerrado-EMBRAPA, Planaltina-DF. \\ ¿Departamento de Zoologia-ESALQ/USP, C.P. 9, CEP: 13418-900, Piracicaba-SP.
}

\begin{abstract}
To evaluate non-conventional phosphorus sources, a group of $\mathbf{4 0 0}$ Nellore cows mantained under pasture received a mineral mixture with different P sources (group I: superphosphate - 500 ppm P; group II: superphosphate - 340 ppm P plus rock phosphate Patos 160 ppm P; group III: superphosphate 340 ppm P plus dicalcium phosphate $160 \mathrm{ppm} P$; group IV - dicalcium phosphate $500 \mathrm{ppm} P$ ). There were no differences in pregnancy rate, calving rate and calving interval. A fluorine deposition in bone was observed for the treatments with superphosphate and rock phosphate $(66.92 \pm 15.53 ; 69.97 \pm 6.5$ and $64.05 \pm 3.35 \%$ respectively for group I, II and III). Superphosphate was almost as good dicalcium phosphate to provide phosphorus for grazing cows aud there was a potentially significant economic advantage over dicalcium phosphate.
\end{abstract}

Key words: phosphorus, cattle, rock phosphate, fluorine

\section{FONTES NĀO CONVENCIONAIS DE FÓSFORO PARA GADO ZEBU NO BRASIL}

RESUMO: Quatrocentas vacas Nelore, mantidas em pastagem, receberam mistura mineral contendo fontes não convencionais de fósforo (grupo I - $500 \mathrm{ppm}$ P-superfosfato triplo; grupo II - 340 ppm P como superfosfato e 160 ppm P como rocha Patos; grupo III - 340 ppm P como superfosfato e 160 ppm P como fosfato bicálicico; grupo IV 500 ppm P como fosfato bicácico). Não se verificou diferenças na taxa de prenhez, porcentagem de nascimento e intervalo entre partos. Observou-se que houve maior concentraçāo de flúor nos ossos para o tratamento com fosfato de rocha. $O$ superfosfato triplo apresentou-se como fonte adequada de $P$ e mostrou vantagem económica em relação ao bicálcico.

Descritores: fósforo, fosfatos, flúor, bovinos

\section{INTRODUCTION}

In Brazil, livestock production levels are low and have remained stagnant for several decades. Forages are low in protein, energy and minerals, particularly phosphorus (LOPES \& NUNES, 1991).

Many research data (McDOWELL, 1985) have shown that growth and reproductive performance increase significantly when grazing cattle are provided with mineral supplementation. In tropical countries average calving percentage was increased from 52 to $74 \%$ by mineral supplementation.

The cost of $P$ supplementation in Brazil is high, and represents about $70 \%$ of the total cost of a mineral mixture. Besides, there is shortage of $P$ supplements. Alternative $P$ sources as rock phosphate and fertilizers are cheaper and could be used in order to minimize those problems.

The present research was carried out to investigate the use of non-conventional $P$ sources to replace the dicalcium phosphate in mineral mixtures for zebu cows in an attempt to reduce the costs of mineralization of the herd, and its effects on reproductive parameters.

\section{MATERIAL AND METHODS}

A private beef herd located in the Central region of Brazil was used. A total of 400 breeding Nelore cows, divided into four groups were

1 Work supported by International Atomic Energy Agency (IAEA)

Sci. agric., Piracicaba, 52(1):78-81, jan./abr. 1995 
maintained under cultivated grass pasture (Brachiaria ssp) with free access to ground water.

Each group was offered a mineral mixture prepared from the normal mixture used on the farm, with different $P$ sources, as follows:

Group I: superphosphate - 500 ppm P.

Group II: superphosphate (340 ppm P) and Patos rock phosphate (160 ppm P).

Group III: superphosphate $(340 \mathrm{ppm}$ P) + Dicalcium (160 ppm P).

Group IV: dicalcium phosphate (500 ppm) normally used in farm.

The mineral mixture composition and chemical analysis are shown in TABLES 1 and 2 .

The mineral supplementation was given in covered wood buckets and its intake was recorded.

During the breeding season natural mating was used ( 1 bull per 25 cows) and pregnancy diagnosis was performed through rectal palpations 60 days after the end of the breeding season. Pregnancy rate, calving rate and calving interval were recorded in two consecutive breeding seasons.

At the beginning and the end of the trial, blood sampling and bone biopsy were carried out in $10 \%$ of the animals for phosphorus and fluorine analysis (LITTLE, 1972).

Discrete data were tested for association by chi-square analysis. The effects of treatments upon reproductive parameters were estimated by least square analysis of variance. Differences between means were compared using the Tukey test.

\section{RESULTS AND DISCUSSION}

The pregnancy rate for the first year was 68.69: $69.00: 77.78$ and $74.75 \%$ respectively for groups I, II, III and IV. In the second year the results were 58.16: 56.12: 57.58 and $62.24 \%$, respectively. There were no statistically significant differences between those results. Between years there were statistical differences $(P<0,01)$, with mean values of 72.54 and $58.52 \%$ for first and second year. It was observed that the pregnancy rate decreased even for the group which received dicalcium phosphate. The reason for this is unknown.
TABLE 1. Composition of mineral mixtures offered to Nelore cows $(\mathrm{g} / 100 \mathrm{~g})$.

\begin{tabular}{|c|c|c|c|c|}
\hline & \multicolumn{4}{|c|}{ GROUP } \\
\hline & I & II & III & IV \\
\hline $\begin{array}{l}\text { Super- } \\
\text { phosphate }\end{array}$ & 17 & 10.2 & 12.10 & -- \\
\hline $\begin{array}{l}\text { Patos rock } \\
\text { phosphate }\end{array}$ & -- & 12.24 & - & -- \\
\hline $\begin{array}{l}\text { Dicalcium } \\
\text { phosphate }\end{array}$ & -- & -- & 6.32 & 21.62 \\
\hline $\mathrm{CaCO}_{3}$ & 10.88 & 10.20 & 7.34 & -- \\
\hline Urea & 30 & 30 & 30 & 30 \\
\hline $\mathrm{ZnSO}_{4}$ & 2.35 & 2.04 & 2.50 & 2.74 \\
\hline $\mathrm{CuSO}_{4}$ & 1.30 & 1.16 & 1.40 & 1.53 \\
\hline $\mathrm{COSO}_{4}$ & 0.03 & 0.03 & 0.03 & 0.03 \\
\hline $\mathrm{KI}$ & 0.02 & 0.02 & 0.02 & 0.02 \\
\hline $\mathbf{S}$ & 2.00 & 2.00 & 2.00 & 2.00 \\
\hline Salt & 36.42 & 32.11 & 38.29 & 4206 \\
\hline
\end{tabular}

For the second year the values are low. For Nelore cows, in Brazil, the observed mean values of pregnancy rate vary between $70-80 \%$.

Calving rate was $58.00 \%$. There were no differences among groups and the values were $58.00,65.00,53.00$ and $56.00 \%$ for groups I, II, III and IV, respectively.

Calving interval mean value was 337.42 \pm 7.83 days $(\mathrm{n}=194)$, and for group I, II, III and IV the values were $335.22 \pm 14.04 ; 334,86 \pm$ 16,$26 ; 329.70 \pm 16.06$ and $349.88 \pm 15.10$ day, respectively. There were no statistical differences. Calving intervals of $12-13$ months are considered optimum under temperate condition (FERREIRA \& SÁ, 1986). However the calving interval values can be misleading, since the calculation is based on those cows exhibiting successive parturitions, thus giving no indication of the proportion that fails 
to conceive (MEIRELLES et al., 1990). A more accurate indication of herd reproductive performance might be the number of open days, provided that it is calculated using the actual days from parturition to conception for cows which became pregnant and a value of 365 days is given to all those which did not successfully remate for a year or more after calving.

TABLE 2 - Chemical analysis of mineral mixtures offered to Nelore cows $(\%)$.

\begin{tabular}{lrrrrr}
\hline \multicolumn{7}{c}{ Dry Matter } & Ash & P & F & Ca \\
\hline \multicolumn{2}{c}{ GROUP } \\
I & 98.24 & 81.96 & 4.62 & 0.26 & 11.9 \\
II & 97.84 & 83.54 & 4.94 & 0.34 & 11.6 \\
III & 96.11 & 84.42 & 5.58 & 0.16 & 10.0 \\
IV & 98.28 & 84.22 & 5.93 & 0.04 & 11.5 \\
\hline
\end{tabular}

Including these aspects in this study, it was possible to detect an effect of group upon the open days $(P<0,05)$. Open day values were $179.28 \pm 13.83 ; 226.34 \pm 13.83 ; 236.88 \pm$ $13.83 ; 211.94 \pm 13.83$. Results obtained with dairy cattle in Brazil (MEIRELLES et al., 1990) showed open day values of 151 . A period of 100 days can be considered acceptable according some authors (FERREIRA \& SÁ, 1986). However with Nelore cattle the open day period is normally longer than for dairy cattle and a period of 150 days is the normal value in tropical conditions.

The mineral mixture intake was 127.78 $\pm 33.20 ; 101.38 \pm 33.04 ; 115.17 \pm 36.98$ and $110.17 \pm 43.00 \mathrm{~g} / \mathrm{head} /$ day, respectively for group I, II, III and IV. Those results gave a phosphorus and fluorine intake of 6.59 and $0.16 ; 5.50$ and $0.48 ; 7.08$ and $0.16 ; 6.51$ and $0.04 \mathrm{~g} / \mathrm{d}$, res, 'actively. It is observed that the mineral mixture and $\mathrm{P}$ intake were lower for group II, although there were no statistical differences. There is a tendency to decrease intake of mineral mixture when animals are fed with rock phosphate due to palatability problems (DAYRELL, 1991).

The intake of fluorine was compared to some obtained by DAYRELL (1991), which observed levels of 0.18 to $0.32 \mathrm{~g} / \mathrm{d}$. In this range, the authors did not find any effect on weight gain and reproductive performance when heifers received rock phosphate as $P$ source. The results obtained in the present work corroborate those findings. The mean values of phosphorus in plasma and phosphorus and fluorine levels in bone are in TABLE 3.

For plasma inorganic $P$ there was no difference among groups and the values are in the normal range (THOMPSON, 1978).

Phosphorus content in bone ash showed statistical differences $(P<0,01)$ and values were lower for group I. Some researchers (AMMERMAN et al., 1974) found that animals with $\mathrm{P}$ content in bone ash between 17.6 and $18.1 \%$ did not show $P$ deficiency, although according to literature (McDOWELL, 1985) level of $17 \%$ is considered critical. The values reported in the present experiment are low compared to those mentioned in literature, even for the animals which received dicalcium phosphate (group IV). For the fluorine content there were differences among groups, and the animals which received dicalcium phosphate presented lower values $(P<$ $0,01)$. The animals which received rock phosphate (group II) had highest fluorine level in bone ash. The percentage of fluorine deposition during the experiment was $66.92 \pm 15.33 ; 69.97 \pm 6.50$ and $64.05 \pm 8.38$ respectively for groups I, II and III. The group IV showed an increase of $42.11 \pm$ $11.96 \%$ in bone fluorine content $(P<0.01)$.

According to literature (DAYRELL, 1991) the fluorine content in bone ash of bovines which received dicalcium phosphate and rock phosphate was 507 and $1370 \mathrm{ppm}$, after one year, and the percentage of fluorine deposition in the animals which received rock phosphate was $114.73 \%$. In those animals, fluorine signs started after 4.5 year after the beginning of the treatment. In the present work the data obtained are in accordance with those indicated although the percentage of fluorine deposition was lower, probably because rock phosphate was mixed with other sources. Signs of fluorosis were not observed after two years of experiment.

The cost of each mineral mixture was $1.08 ; 1.21 ; 2.02$ and $2.92 \mathrm{US} \$ / 100 \mathrm{head} /$ day for group I, II, III and IV, respectively. It is observed that cost for DP is approximately three times more than when superphosphate is used.

It may be stressed that there were no differences in the reproductive data when DP or the other sources were used. However, the results for 
TABLE 3 - Phosphorus and fluorine levels in plasma and bone ash of zebu cows.

\begin{tabular}{llcl}
\hline & $\begin{array}{l}\text { phosphorus in } \\
\text { plasma }(\mathrm{mg} \%)\end{array}$ & $\begin{array}{c}\text { phosphorus in } \\
\text { bone (\%) }\end{array}$ & $\begin{array}{c}\text { fluorine in } \\
\text { bone (ppm) }\end{array}$ \\
\hline Group I & $5.08 \pm 0.30^{\mathrm{a}}$ & $12.96 \pm 0.16^{\mathrm{a}}$ & $1069.90 \pm 135.77^{\mathrm{a}}$ \\
Group II & $4.81 \pm 0.30^{\mathrm{a}}$ & $13.41 \pm 0.16^{\mathrm{b}}$ & $1608.23 \pm 135.77^{\mathrm{c}}$ \\
Group III & $4.64 \pm 0.32^{\mathrm{a}}$ & $13.72 \pm 0.16^{\mathrm{b}}$ & $776.06 \pm 135.77^{\mathrm{b}}$ \\
Group IV & $4.38 \pm 0.31^{\mathrm{a}}$ & $13.60 \pm 0.16^{\mathrm{b}}$ & $632.37 \pm 135.77^{\circ}$ \\
\hline
\end{tabular}

a,b,c Means in a column with different letters are significantly different.

fluorine content in bone must be taken in account, since future problems of fluorosis could occur.

\section{CONCLUSION}

From the present findings it could be concluded that superphosphate was almost as good as dicalcium phosphate to provide phosphorus for grazing zebu cattle, and there is a potentially significant economic advantage of this source over dicalcium. Results of high fluorine content in bone suggest, however, the possibility of future fluorosis problems.

\section{REFERENCES}

AMMERMAN, C.B.; LOAIZO, J.M.; BLUE, W.C.; GAMBLE, S.F.; MARTIN, G.F. Mineral composition of tissues from beef cattle under grazing conditions in Panamá. Journal of Animal Science, Albany, v.38, p.158-162, 1974.

DAYRELL, M.S. Desempenho de bovinos alimentados durante longos períodos com fosfato Tapira. In: MINI SIMPÓSIO DO COLÉGIO BRASILEIRO DE NUTRIÇÃO ANIMAL, 4., 1991, Campinas. Anais... Campinas, CBNA, 1991.p.167-176.

FERREIRA, A.M.; SÁ, W.F. Desmama temporária e atividade ovariana pós-parto em bovinos de leite. Revista da Sociedade Brasileira de Zootecnia, Viçosa, v.15, p.175-178, 1986.
LITTLE, D.A. Bone biopsy in cattle and sheep for studies of phosphorus status. Australian Veterinary Journal, Sydney, v.48, p.668-670, 1972.

LOPES, M.O.S.; NUNES, I.J. Potential of utilization of feed resources of Brazilian Cerrados to grazing livestock In: INTERNATIONAL SYMPOSIUM ON THE UTILIZATION OF FEED RESORCE IN RELATION TO NUTRITION AND PHYSIOLOGY OF RUMINANTS IN THE TROPICS, 1991, Ibaraki. Ibaraki, TARC, 1991. p.1-9.

McDOWELL, L.R. Nutrition of grazing ruminants in warm climates. Orlando: Academic Press, 1985. 443p.

MEIRELLES, C.F.; ABDALLA, A.L.; VITTI, D.M.S.S.; PEÇANHA, M.R.S. Reinício da atividade ovariana no pós-parto em vacas holandesas do rebanho da ESALQ. Anais da Escola Superior de Agricultura "Luiz de Queiroz", Piracicaba, v.45, p.179-189, 1990.

THOMPSON, W.R. Phosphorus in animal nutrition. In: POTASH \& PHOSPhate. Phosphorus for agriculture: a situation analysis. Atlanta, 1978. p.126-138.

Entregue para publicação em 01.06 .94

Aceito para publicação em 12.07.94 